Klinik Araştırma/ Clinical Research

\title{
Üniversite hastanesi sağlık çalışanlarında HBV, HCV ve HIV seropozitifliğinin hastaneye başvuranlarla karşılaştırılması
}

\section{Comparing seropositivity of $\mathrm{HBV}, \mathrm{HCV}$ and $\mathrm{HIV}$ in health care workers with those admitted to hospital}

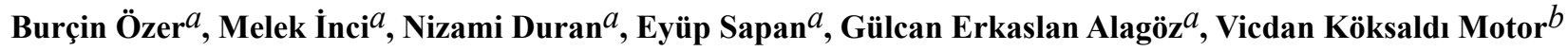

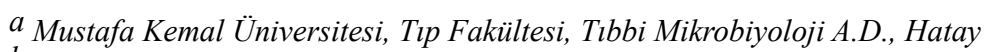

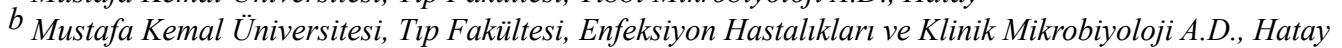

\begin{tabular}{|c|c|}
\hline MAKALE BİLGİLERİ & ÖZET \\
\hline Makale Geçmişi: & \multirow{16}{*}{ 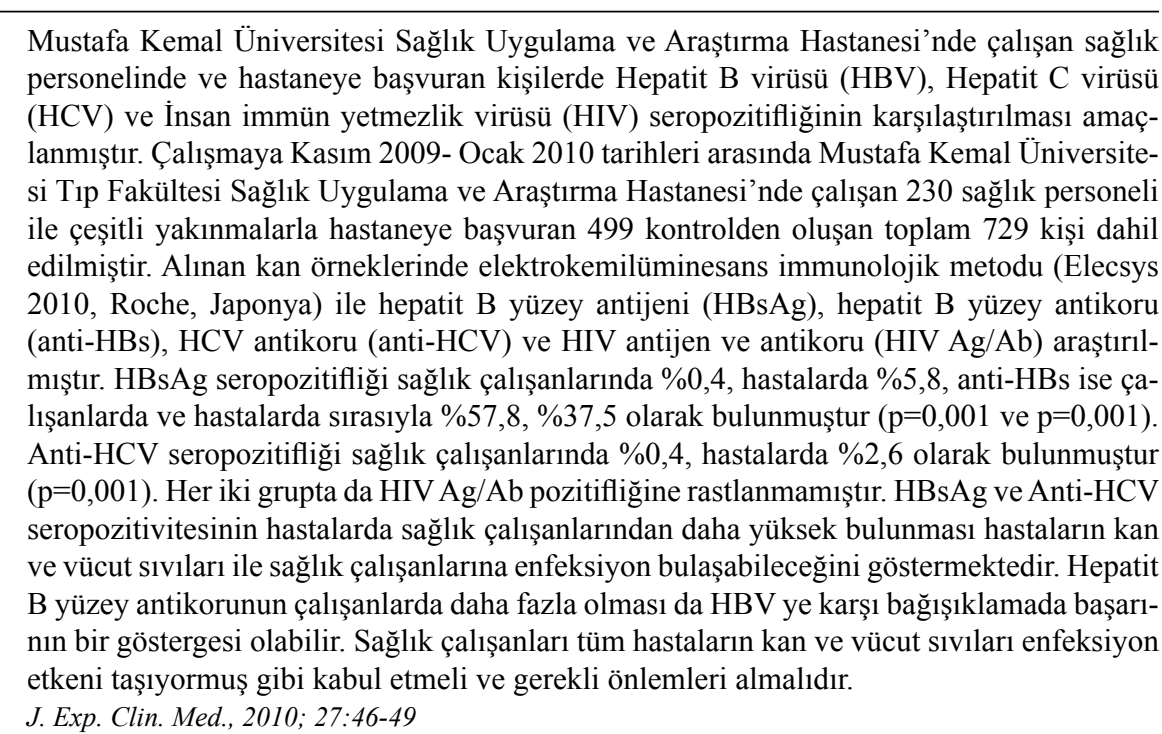 } \\
\hline $01 / 07$ / 2010 & \\
\hline $19 / 07 / 2010$ & \\
\hline * Yazışma Adresi: & \\
\hline Burçin Özer & \\
\hline Mustafa Kemal Üniversitesi, & \\
\hline Tayfur Ata Sökmen Tıp Fakültesi, & \\
\hline Tibbi Mikrobiyoloji Anabilim Dalı, & \\
\hline Antakya, Hatay & \\
\hline e-posta: burcinozer@yahoo.com & \\
\hline Anahtar Kelimeler: & \\
\hline Sağlık Çalışanları & \\
\hline HBV & \\
\hline $\mathrm{HCV}$ & \\
\hline HIV & \\
\hline & \\
\hline
\end{tabular}

\section{Key Words:}

Health Care Workers

$\mathrm{HBV}$

$\mathrm{HCV}$

HIV

University Workers

\begin{abstract}
The aim of this study is to compare the seropositivity of HBV, HCV and HIV in health care workers of Mustafa Kemal University Hospital with the people admitted to hospital. In the study 230 health care workers and 499 controls who admitted to the hospital with several complaints, totally 729 people were included between November 2009 and January 2010. hepatitis B surface antigen (HBsAg), Hepatitis B surface antibody (anti-HBs), HCV antibody (anti-HCV) and HIV antigen and antibody ( $\mathrm{HIV} \mathrm{Ag/Ab)} \mathrm{were} \mathrm{investigated} \mathrm{using}$ electrochemiluminescent immunological method (Elecsys 2010, Roche, Japan) in blood samples obtained from subjects. The seropositivity of HBsAg was found $0.4 \%$, in health care workers while it was found as $5.8 \%$ in controls, and the seropositivity of anti-HBs was found $57.8 \%$ in health care workers while it was found $37.5 \%$ in controls $(\mathrm{p}=0.001$ and $\mathrm{p}=0.001$ ). The seropositivity of anti-HCV was found $0.4 \%$ in health care workers and $2.6 \%$ in patients $(\mathrm{p}=0.001)$. The positivity of HIV Ag/Ab was not observed in both groups. The higher seropositivity of HBsAg and Anti-HCV in controls than health care workers showed that infections can be transmitted via blood and body fluids of patients. Higher surface antibody rates in health care workers might be an indicator of success of immunization against hepatitis B. The health care workers should accept all blood and body fluid of patients as contaminated and take necessary preventive measure.

J. Exp. Clin. Med., 2010; 27:46-49
\end{abstract}

(C) 2010 OMÜ Tüm Hakları Saklıdır.

\section{Giriş}

Hepatit B virüs (HBV) enfeksiyonu, global bir halk sağlığı sorunudur ve dünyada en sık görülen bulaşıcı hastalıklardan birisidir. Dünya Sağlık Örgütünün (DSÖ) verilerine göre dünya nüfusunun üçte birinden fazlasının HBV ile enfekte olduğu tahmin edilmektedir (İyigün ve 
Avc1, 2009). Dünyada farklı bölgelerde endemisite değişmektedir. Ülkemiz orta endemisite bölgeleri arasında yer almaktadır (Demir ve ark., 2006; Akca, 2008). HBV enfeksiyonunun başlıca geçiş yolları; perinatal, cinsel temas, intravenöz ilaç kullanımı, kontamine kan ürünleri ile temas, mesleki temaslar ve insandan insana bulaştır (İyigün ve Avc1, 2009).

HCV seroprevalansının dünyada $\% 0,5-2$, ülkemizde ise değişik çalışmalarda değişik oranlar verilmekle beraber sağlik personelinde $\% 1,6$, kan donörlerinde $\% 0,3-$ 0,5 olduğu bildirilmiştir (Akca, 2008). 2005 yılı itibariyle HIV ile enfekte kişi sayısının yaklaşık olarak dünya üzerinde 40 milyon, ülkemizde ise 2500 civarında olduğu belirtilmiştir (Akca, 2008).

Sağlik çalışanları meslekleri nedeniyle pek çok enfeksiyon etkenine maruz kalmaktadır. Hastanelerin viral, bakteriyel, fungal ve protozoon hastalıkların bulaşması ve yayılması bakımından sağlık çalışanları için toplumun diğer kesimlerine göre daha yüksek oranda risk taşıdıkları bilinmektedir. Özellikle ameliyathane, yoğun bakım, laboratuvar ve acil servislerde çalışanlar kan, vücut sıvıları gibi enfekte hasta materyalleri ile temas etmektedirler. $\mathrm{Bu}$ durum kan yoluyla bulaşan hastalı etkenleriyle daha s1k karşılaşmalarına yol açmaktadır. Bu konu ile ilgili daha önce çalışmalar yapılmıştır ancak diğer populasyonlarla karşılaştırma yapılan çalışma sayısı azdır.

Bu çalışmada Mustafa Kemal Üniversitesi Sağlık Uygulama ve Araştırma Hastanesi'nde çalışan hastane personelinde $\mathrm{HBV}$, Hepatit $\mathrm{C}$ virüsü $(\mathrm{HCV})$ ve insan immün yetmezlik virüsü (HIV) seropozitifliğinin belirlenmesi ve bu sonuçların hastaneye başvuran kişilerle karşılaştırılmas1 amaçlanmıştır.

\section{Araştırma Yöntemi}

Bu çalışma Kasım 2009-Ocak 2010 tarihleri arasında Mustafa Kemal Üniversitesi Tip Fakültesi Sağlık Uygulama ve Araştırma Hastanesi'nde yürütülmüştür. Çalışmaya 230 hastane çalışanı ile çeşitli yakınmalarla farklı polikliniklere başvuran 499 kişi dahil edilmiştir. Araştırmaya katılanlardan alınan kan örneklerinin serumları ayrıldıktan sonra hemen çalışmaya alınmıştır. Serumlarda elektrokemilüminesans immunolojik metodu (Elecsys 2010, Roche, Japonya) ile hepatit B yüzey antijeni (HBsAg), hepatit B yüzey antikoru (anti-HBs), HCV antikoru (anti-HCV) ve HIV antijen ve antikoru (HIV Ag/ Ab combi (HIV-1 + HIV-2 + HIV subtip 0 antikorları ve p24 antijeni) araştırılmıştır.

Anti-HCV sonuçları $2 \mathrm{kez}$ tekrar edilmiş ayrıca gerçek zamanlı PCR yöntemi ile çalışılan HCV-RNA testi ile (Taqman-Roche, İsviçre) doğrulanmıştır.

İstatistiksel analiz SPSS programında yapılmış ve gruplar arası karşılaştırmalarda ki-kare, Fisherin kesin testi ve Student's $t$ testi kullanılmıştır. $p<0,05$ anlamlılık sınırı olarak kabul edilmiştir.

\section{Bulgular}

Çalışmaya katılan hastane personelinin 109'u
$(\% 47,4)$ kadın, 121'i $(\% 52,6)$ erkek, hastaların ise 262'si kadın $(\% 52,5), 237$ 'si $(\% 47,5)$ erkekti $(\mathrm{p}=0,199)$. Sağlık çalışanlarının yaşları 19-59 (yaş ortalaması 31,6 \pm 7,9), hastaların yaşları ise 19-86 (yaş ortalaması 49,5 $\pm 17,8$ ) arasında değişmekteydi $(\mathrm{p}=0,001)$. Sağlık çalışanlarının 99'u (\%43) temizlik personeli, 72'si $(\% 31,3)$ büro çal1şanı, 25'i $(\% 10,9)$ hemşire, 18 'i $(\% 7,8)$ sağlık teknisyeni, 16 's1 $(\% 3,9)$ yemekhane ve teknik destek personeliydi.

HBsAg sağlık çalışanlarının 1'inde $(\% 0,4)$, hastaların 29'unda $(\% 5,8)(\mathrm{p}=0,001)$, anti-HBs çalışanların 133 'ünde $(\% 57,8)$, hastaların 187 'sinde $(\% 37,5)$ pozitif olarak bulunmuştur $(\mathrm{p}=0,001)$. Anti-HCV ise sağlık çal1şanlarının 1'inde $(\% 0,4)$, hastaların 13'ünde $(\% 2.6)$ pozitif olarak saptanmıştır $(p=0,001)$. Her iki grupta HIV Ag/Ab pozitifliğine rastlanmamıştır. Her iki grubun demografik özellikleri ve seroprevalans durumunun karşılaştırılması Tablo 1'de gösterilmiştir.

Tablo 1. Her iki grubun demografik özellikleri ve seropozitiflik durumu.

\begin{tabular}{|l|l|l|l|}
\hline & $\begin{array}{l}\text { Sağlık çalışanları } \\
(\mathrm{n}=230)\end{array}$ & Hastalar $(\mathrm{n}=499)$ & p değeri \\
\hline Yaş & $31,6 \pm 7,9$ & $49,5 \pm 17,8$ & 0,001 \\
\hline Cinsiyet(kadın/erkek) & $109 / 121$ & $262 / 237$ & 0,199 \\
\hline HBsAg pozitif & $1(\% 0,4)$ & $29(\% 5,9)$ & 0,001 \\
\hline Anti-HBs pozitif & $133(\% 57,8)$ & $187(\% 37,5)$ & 0,001 \\
\hline Anti-HCV pozitif & $1(\% 0,4)$ & $13(\% 2,6)$ & 0,001 \\
\hline HIV Ag/Ab pozitif & - & - & - \\
\hline
\end{tabular}

Sağlık çalışanları mesleklere göre 5 gruba ayrılmıştır. Meslek grupları ve seroprevalans durumları Tablo 2'de gösterilmiştir.

Tablo 2. Sağlık çalışanlarının meslek gruplarına göre seroprevalans durumları

\begin{tabular}{|l|l|l|l|l|}
\hline Meslek grupları & $\begin{array}{l}\text { HBsAg } \\
\text { Pozitif }\end{array}$ & $\begin{array}{l}\text { Anti-HBs } \\
\text { Pozitif }\end{array}$ & $\begin{array}{l}\text { Anti-HCV } \\
\text { Pozitif }\end{array}$ & $\begin{array}{l}\text { HIV Ag/Ab } \\
\text { Pozitif }\end{array}$ \\
\hline $\begin{array}{l}\text { Temizlik person- } \\
\text { eli }(\mathrm{n}=99)\end{array}$ & $1(\% 1)$ & $61(\% 61,6)$ & $1(\% 1)$ & - \\
\hline $\begin{array}{l}\text { Büro çalışanı } \\
(\mathrm{n}=72)\end{array}$ & - & $36(\% 50,0)$ & - & - \\
\hline Hemşire (n=25) & - & $20(\% 80,0)$ & - & - \\
\hline $\begin{array}{l}\text { Sağlık teknisyeni } \\
(\mathrm{n}=18)\end{array}$ & - & $15(\% 83,3)$ & - & - \\
\hline *Diğer $(\mathrm{n}=16)$ & - & $1(\% 6,25)$ & - & - \\
\hline
\end{tabular}

*yemekhane ve teknik destek personeli

Sağlık çalışanlarının kendi aralarında meslek gruplarına göre analizi yapıldığında anti-HBs seropozitifliği temizlik personeli, hemşireler ve sağlık teknisyenlerinde, büro personeli ve diğer gruba göre daha yüksek oranda bulunmuştur ( $\mathrm{p}=0,001)$ (Tablo 3$)$.

Tablo 3. Sağlık çalışanlarının mesleklere göre anti-HBs seropozitifliği

\begin{tabular}{|l|c|c|c|}
\hline \multirow{2}{*}{ Meslek Grupları } & \multicolumn{2}{|c|}{ Anti-HBS } & \multirow{2}{*}{ p değeri } \\
\cline { 2 - 3 } & Negatif(\%) & pozitif (\%) & \\
\hline Temizlik personeli & 38 & 61 & \\
\hline Büro çalışanı & 36 & 36 & \multirow{2}{*}{0,001} \\
\hline Hemşire & 5 & 20 & \\
\hline Teknisyen & 3 & 15 & \\
\hline Diğer & 15 & 1 & \\
\hline
\end{tabular}


Hastane personelinin meslek gruplarına göre antiHBs seropozitifliği Tablo 3’te gösterilmiştir. Diğer bakılan serolojik parametrelerde ise meslek grupları arasında anlamlı bir fark bulunmamıștır.

\section{Tartıșma}

Hepatit virüsleriyle enfeksiyon halen tüm dünyay1 ilgilendiren önemli bir sorundur (Kantarçeken, 2009). HBV taşıyıcılığının ortalama dünyada $\% 6,5$, ülkemizde ise yayınlara göre değişmekle beraber \%4-14 arasında olduğu bildirilmektedir. HCV seroprevalansının ise yine çalışmalara göre değişmekle beraber dünyada $\% 0,5-2$, yurdumuzda \%0,3-1,6 civarında olduğu bildirilmektedir (Akca, 2008). HBV ve HCV için en büyük risk grubunu ise sağlık çal1şanları oluşturmaktadır (Akca, 2008). 1992 yılında DSÖ HBV'yi meslek hastalığı olarak kabul etmiş, 1996 yılında ise Sağlık Bakanlığı sağlık çalışanlarının HBV yönünden taranıp uygun kişilerin aşılanmasını başlatmıştır (Ergönül ve ark., 2001). Ülkemizde gerek sağlık çalışanlarında gerekse diğer gruplarda hepatit virüslerinin seroprevalansını araştırmak için çeşitli çalışmalar yapılmıştır (Demir, 2006; İnci ve ark., 2009; Öksüz ve ark., 2009; Güzelant ve ark., 2008; Şencan ve ark., 2003). Hastane çalışanlarında HBV taşıyıcılığının araştırıldığ 1 değişik çalışmalarda HBsAg seropozitifliğini Şencan ve ark. (2003). \%2, Öksüz ve ark. (2009) \%1,7 olarak bulmuşlardır. Yapılan bir çalışmada (Demir ve ark., 2006) bu oran Isparta ili sağlık personelinde \%3, başka bir çalışmada (Güzelant ve ark., 2008) ağız diş sağllğ tir. Sağlık personelinde HBsAg seropozitifliğini Bölükbaş ve ark. (2004) \%3, olarak bulurken, İnci ve ark. (2009) \%1 olarak bulduklarını bildirmişlerdir. Koruk ve ark. (2009) bir ağız ve diş sağlığı merkezi çalışanlarında \%3,6 HBsAg seropozitifliği bulurken, Özsoy ve ark (2003) sağl1k personelinde bu oran $1 \% 3$ olarak bildirmişlerdir.

Sağlık çalışanlarında bu konu ile yapılan çalışmalarda genellikte sadece seropozitiflik oranı verilmiş diğer populasyonlarla karşılaştırma yapılmamıştır. Bizim çalışmamıza benzer olarak diğer populasyonla karşılaştırmalı yapılan çalışmalardan biri olan Karslıgil ve ark.(2007)'nın çalışmasında sağlık çalışanları ile normal popülasyon karşılaştırılmış ve iki grup arasında istatistiksel olarak anlamlı bir fark bulunamamıştır. Bu farklılı̆̆ın sebebi karşılaştırma grubu olarak normal populasyonun alınması olabilir. Karşılaştırmalı yapılan diğer bir tez çalışmasında 648 sağlık çalışanı ve kontrol grubu olarak herhangi bir şikayeti olmayan check-up için hastaneye başvuran 507 sağ lkl $_{1}$ kişi çalışmaya dahil edilmiştir (Aşkar, 2006). Bu çalışmada bizim çalışmamızla uyumlu olarak HBsAg pozitifliği sağlık çalışanlarına kıyasla normal popülasyonda anlamlı oranda yüksek bulunmuştur (Aşkar, 2006). HBsAg pozitifliğinin sağlık çalışanlarında hastaneye başvuranlardan daha düşük oranda bulunması personelin risklerin farkında olup korunma önlemlerine önem vermeleri ile açıklanabilir. Yurdumuzda sağlık çalışanlarının HBV'ye karşı bağışık olup olmadığının araştırıldığı birçok çalışma mevcuttur (Demir ve ark., 2006; İnci ve ark., 2009; Güzelant ve ark., 2008; Koruk ve ark., 2009). Sağlık personelinde yapılan çalışmalarda anti-HBs pozitifliğini Demir ve ark. (2006) $\% 78,3$, İnci ve ark. (2009) ise \%62,7 olarak bildirmişlerdir. Anti-HBs pozitifliği bir ağız ve diş sağlığı merkezi çalışanlarında \%63 (11), bir başka ağız ve diş sağlığı merkezi çalışanlarında \%41,2 (8) olarak bulunmuştur. Aşkar'ın çalışmasında sağlık çalışanlarında $\% 73$ ve kontrol grubunda ise $\% 22$ anti-HBs seropozitifliği bildirilmiştir $(p<0,05)$. Bizim çalışmamızda da Aşkar'ın çalışması ile uyumlu olarak anti-HBs pozitifliği sağlık çalışanlarında, hastalardan daha yüksek olarak tespit edilmiştir (Aşkar, 2006). Bu durum hastane personelinin bağışıklama programlarına verdiği önemle açıklanabilir.

İnan ve ark., (2005) yaptıkları çalışmada kan veya vücut sıvilarıyla en fazla temasta olan grubun hemşireler, ikinci sırada temizlik personeli olduğunu bulmuşlardır. Sarı ve ark. (2006) çalışmalarında temizlik şirketi çalışanlarının da en az diğer personel kadar risk altında olduğunu vurgulamışlardır. Bizim çalışmamızda ise sağlık çalışanlarının kendi aralarında meslek gruplarına göre analizi yapıldığında anti-HBs pozitifliğinin temizlik personeli, hemşireler ve sağlik teknisyenlerinde nispeten daha az riskli bölümde çalışan ve hasta ile birebir teması olmayan büro personeli ve diğer gruba göre daha yüksek bulunduğu görülmüştür. Daha riskli bölümde çalışan personelde daha fazla bağışıklık oranlarının bulunması, o bölümde çalışanların korunma önlemlerine ve bağışıklanmaya daha fazla önem vermeleri ile açıklanabilir.

Yurdumuzda HCV'nin prevalansı HBV'ye kıyasla daha düşük olmasına karşın sonuçları itibariyle hem normal popülasyon, hem de hastane personeli için önemlidir (Dilek, 2007). Anti-HCV seropozitifliği Düzce Atatürk Devlet Hastanesi çalışanlarında \%0,2, Kayseri Doğumevi Hastanesi personelinde \%0,34 olarak bulunmuştur (İnci ve ark., 2009; Öksüz ve ark.,2009). Koruk ve ark. (2009) bir ağız ve diş sağlı̆̆ 1 merkezi çalışanlarında anti-HCV seropozitifliğini \%0,3 olarak bulmuşlardır. Güzelant ve ark. (2008) çalışmalarında kan donörlerinde HCV seroprevalansını \%0,1 olarak bulurken, sağlık çalışanlarında seropozitifliğe rastlamadıklarını bildirmişlerdir. Sağlık personelinde yapılan iki farklı çalışmada anti-HCV seropozitifliği bulunmadığı bildirilmiştir (Sarı ve ark., 2006; Doğan ve ark., 2005). Aşkar'ın yaptığı çalışmada ise anti-HCV seropozitifliği sağlı personelinde ve kontrol grubunda benzer olarak bulunmuş (\%0,15 ve \%0,7 ) (Aşkar, 2006), bizim çalışmamızda ise anti-HCV seropozitifliği sağlık çalışanlarında hastalardan daha az olarak bulunmuştur DSÖ 2005 yılı Aralık ayı verilerinde dünyada HIV ile enfekte kişi sayısını 36,7-45,3 milyon, aynı yıl Sağlık Bakanlığı ise HIV pozitif kayitlı hasta sayısın 2544 olarak bildirmiştir (Akca, 2008). Güzelant ve ark. (2008) hem sağlik personelinde hem de kan donörlerinde HIV pozitifliğine rastlamadıklarını bildirmişlerdir. Hastane çalışanlarında yapılan iki farklı çalışmada HIV seropozitifliği bulunmadığ 1 bildirilmiştir (İnci ve ark., 2009; Bölükbaş ve ark., 2004). Çalışmamızda sağlık çalışanlarında ve hastalarda HIV seropozitifliği bulunmamıştır. Bulgularımız ülkemizdeki diğer çalışmalarla uyumludur. 
Sonuç olarak; HBsAg ve Anti-HCV seropozitivitesi hastalarda sağlık çalışanlarından daha yüksek olarak bulunmuştur. $\mathrm{Bu}$ da hastaların kan ve vücut sıvıları ile sağlık çalışanlarına enfeksiyon bulaşabileceğini göstermektedir. Anti-HBs çalışanlarda hastalardan daha fazla bulunmuştur. $\mathrm{Bu}$ da HBV bağışıklanması ile ilgili sağl1k çalışanlarına verilen eğitimlerin faydalı olduğunu ve sağllk çalışanlarının HBV bağışıklanmasına gereken önemi ver- diğini göstermektedir. HIV taşıyıcılığı, ülkemiz açısından önemli bir sorun olarak görünmese de bulaş olduğunda yol açacağı sonuçlar gözönüne alındığında çalışan güvenliğine yönelik önlemlere azami özen gösterilmeli, bulaş riskinin yüksek olduğu hastalarda girişim öncesi HIV açısından tarama yapılmalıdır. Sağlık çalışanları tüm hastaların kan ve vücut sıviları enfeksiyon etkeni taşıyormuş gibi kabul etmeli ve gerekli önlemleri almalıdır.

\section{KAYNAKLAR}

Akca, G., 2008. Diş hekimliğinde kan yoluyla bulaşan viral enfeksiyonlar ve önemi. Hastane İnfeksiyonları Dergisi 12, 5-10.

Aşkar, E., 2006. Sağlık çalışanlarında hepatit B ve hepatit C seroprevalansı. Şişli Etfal Eğitim ve Araştırma Hastanesi Enfeksiyon Hastalıkları ve Klinik Mikrobiyoloji Kliniği, uzmanlık tezi, İstanbul.

Bilgiç, A., Özacar, T., 2002. Hepatit B virusu. İnfeksiyon Hastalıkları ve Mikrobiyolojisi. Eds: Topçu AW, Söyletir G, Doğanay M. Nobel tip kitabevleri. Cilt 2. pp. 1350-1370.

Bölükbaş, F.F., Zeyrek, F.Y., Bölükbaş, C., Zeyrek, C.D., Uzunköy, A., Tabur, S., Özbilge, H., 2004. Hasta bakımı ve hastane hijyeninden sorumlu sağlık personelinde HBV, HCV ve HIV sıklığı. Viral Hepatit Derg. 9, 89-92.

Demir, İ., Kaya, S., Demirci, M., Arıdoğan, B.C., 2006. Isparta ili sağlık personelinde hepatit B virus seropozitifliğinin araştırılması. İnfeksiyon Derg. 20, 183-187.

Dilek, İ., Demir, C., Bay, A., Akdeniz, H., Öner, A.F., 2007. Seropositivity rates of HBsAg, anti-HCV, anti-HIV and VDRL in blood donors in Eastern Turkey. Turk J. Hematol. 24, 4-7.

Doğan, G.B., Bayındır, Y., Kayabaş, Ü., Tekerekoğlu, M.S., Yoloğlu, S., Ersoy, Y., 2005. Diş hekimleri ve yardımcı sağlık personeli arasında hepatit B ve C seroprevalansı. Klimik Derg. 18, 121-124.

Ergönül, Ö., Işık, H., Baykan, N., Erbay, A., Dokuzoğuz, B., Müftüoğlu, O., 2001. Ankara Numune Eğitim ve Araştırma Hastanesi’nde sağlık çalışanlarında hepatit B enfeksiyonu. Viral Hepatit Derg. 2, 327-329.

Güzelant, A., Kurtoğlu, M.G., Kaya, M., Keşli, R., Baysal, B., 2008. Kan vericilerinde ve bir ağız-diş sağlığı merkezi çalışanlarında hepatit B, hepatit C ve HIV seroprevalansı ile vericilerde risk faktörlerinin araştırılması. İnfeksiyon Derg. 22, 189-195.

İnan, D., Günseren, F., Selçuk, K., Harman, R., Keskin, S., Çolak, D., 2005. Akdeniz Üniversitesi Hastanesi sağlık çalışanlarının kan veya vücut sivılarıyla mesleki teması. Viral Hepatit Derg. 10, 109-113.

İnci, M., Aksebzeci, A.T., Yağmur, G., Kartal, B., Emiroğlu, M., Erdem, Y., 2009. Hastane çalışanlarında HBV, HCV ve HIV seropozitifliğinin araştırılması. Türk Hij. Den. Biyol. Derg. 66, 59-66.

İyigün, C.P., Avcı, İ.Y., 2009. Hepatit B ve D virüsleri. Eds: Başustaoğlu A, Kubar A, Yıldıran ŞT, Tanyüksel M. Klinik Mikrobiyoloji Cilt 2. 9. Baskı Atlas kitapçılık Ankara, pp.1641-1659.

Kantarçeken, B., 2009. Kronik hepatit B - doğal seyir. eds. Tabak F, Balık İ. Viral hepatit kitabı Viral hepatitle savaşım derneği yayın1, pp, 3-22

Karslıgil, T., Uygur, O., 2007. Sağlık personeli ve toplumda hepatit B virüsüne karşı oluşan doğal bağışıklık ve immünizasyonla gelişen antikor düzeylerinin araştırılması. Gaziantep Tıp Derg. 1,31-34.

Koruk, S.T., Koruk, İ., Şahin, M., Duygu, F., 2009. Şanlıurfa'da ağız ve diş sağlığı çalışanlarında HBsAg, Anti-HBs ve Anti-HCV pozitifliği ve risk faktörlerinin değerlendirilmesi. Klimik 22, 55-61.

Öksüz, Ş., Yıılııım, M., Özaydın, Ç., Şahin, İ., Arabacı, H., Gemici, G., 2009. Bir devlet hastanesi çalışanlarında HBV ve HCV seroprevalansının araştırılması. ANKEM Derg. 23, 30-33.

Özsoy, M.F., Öncül, O., Çavuşlu, S., Erdemoğlu, A., Emektaş, G., Pahsa, A., 2003. Seroprevalences of hepatitis B and hepatitis C among health care workers in Turkey. J. Viral Hepat. 10, 150-156.

Sarı, N., Günal, Ö., Dizbay, M., Hızel, K., Aktaş, F., 2006. Bir üniversite hastanesinde temizlikten sorumlu şirket elemanlarında ve sözleşmeli hemşirelerde HBsAg ve anti-HCV sıklı̆ı̆ını araştırılması. Viral Hepatit Derg. 11, 126-131.

Şencan, İ., Şahin, İ., Kaya, D., Bahtiyar, Z., 2003. Yeni kurulan bir tıp fakültesi hastanesi’nde sağlık çalışanlarının hepatit B ve hepatit C seroprevalansı. Viral Hepatit Derg. 8, 47-50. 